longueurs d'onde, et des tables de spectres solaires, en exprimant le désir qu'aurait cette Union, de voir le Comité international des Poids et Mesures établir un texte renouvelé, relatif aux spécifications de la lampe à cadmium Michelson, susceptible d'émettre la raie rouge étalon des longueurs d'onde lumineuses.

Pour répondre à cette demande, $j$ 'ai l'honneur de vous remettre le texte ci-inclus, qui, s'inspirant de cette Note, a été élaboré par notre Commission spéciale des longueurs d'onde lumineuses (MM. Zeeman, Cabrera, Kösters, MacLennan, Nagaoka, Sears, Pérard), et approuvé par le Comité international en séance plénière. En adoptant ce texte, qui donne les spécifications qui ont paru les meilleures pour l'émission de la raie de référence 6438.4696 UA, dans la lampe du type Michelson, le Comité a néanmoins exprimé l'avis que devait être réservée à l'expérimentateur la liberté d'employer éventuellement d'autres sources dans des conditions convenablement choisies.

En remerciant vivement votre Union d'avoir bien voulu consulter notre Comité à cette occasion, je vous prie d'agréer, Monsieur le Président, les assurances de ma bien haute considération et de mes sentiments sincèrement dévoués.

Le Président du Comité international des Poids et Mesures,

Monsieur le Président

V. A. VOLTERRA de l'Union Astronomique Internationale

Spécifications pour la lampe à cadmium du type Michelson

Pour émettre dans des conditions favorables la raie primaire des longueurs d'onde lumineuses $\lambda=6438 \cdot 4696$ UA, la lampe à cadmium du type Michelson, comportant des électrodes intérieures et excitée par courant électrique, continu ou alternatif de fréquence industrielle, doit être maintenue à une température voisine de $300^{\circ} \mathrm{C}$. (en tout cas ne dépassant pas $320^{\circ} \mathrm{C}$.), et contenir de l'air sous une pression comprise entre $0.7 \mathrm{~mm}$. et I $\mathrm{mm}$. de mercure à cette température. Si elle présente un tube capillaire ou plus généralement un étranglement destiné à augmenter sa brillance, aucune dimension latérale de cet étranglement ne devra être inférieure à $2 \mathrm{~mm}$. L'intensité du courant d'excitation ne dépassera pas une valeur telle que sa densité risque d'atteindre $7 \mathrm{~mA}$. par millimètre carré de la section la plus étroite de la région observée.

\title{
COMMISSION I6. (PLANETS, COMETS AND SATELLITES.)
}

\author{
President: Rev. T. E. R. Phillips. \\ SeCRETARY: Mr C. LUPLAU-JansSen.
}

The President referred to two matters left over from the meeting at Cambridge, Mass. in I932, viz. (a) the formation of a small sub-committee on Martian Nomenclature, and $(b)$ the appointment of a Secretary to deal with the work on the physical study of comets. He had requested Messrs Antoniadi, Lampland, and Maggini to form the Committee on Martian Nomenclature, but the question was difficult and complicated, and it had not yet been found possible to come to a conclusion apart from the acceptance of the nomenclature of Schiaparelli as an agreed basis. 
Dr Bobrovnikoff had been asked to act as Secretary for Comets, and his report was included in the draft report of the Commission.

A proposal to ask for a division of the scope of the Commission by transferring the physical study of comets to another commission was considered. Only a few members voted, and the proposal was not carried.

During the consideration of the draft report the President made special reference to the recent interpretation of the spectra of the great planets, and the knowledge thereby gained of the composition and constitution of their atmospheres. Mention was also made of the study by Professor Stroobant of the problem of the alleged eccentricity of Saturn's rings, and it was recommended that observations on the lines indicated by him should be continued.

Considerable discussion followed on the colouration of the surface features of Jupiter. It was agreed that although instrumental and personal factors enter into the problem the differences of colour were real, and that it was desirable that close attention be given to the study of them by all suitable means, and especially by observers having the use of large instruments.

The draft report was adopted with additions.

\section{COMMISSION I7. (LUNAR NOMENCLATURE.)}

President: Sir Frank Dyson.

SeCretary: M. G. Delmotte.

The President reported that the work of the Commission had been achieved and two volumes published and distributed. These are: (I) a volume of named lunar formations and (2) a volume of $\mathrm{I}_{4}$ maps with corresponding names upon them.

After some discussion it was proposed to recommend that the Commission should be continued on a broader basis and called "La Lune"-but divided into three sub-commissions.

(r) Visual and Photographic Observations of the Surface.

(2) Physical Observations.

(3) Mathematical researches and occultations.

\section{COMMISSION I8. (LONGITUDES.)}

President: Général G. Perrier.

SECRETARY: Rev. R. P. LEJAY.

Après lecture du rapport par le Président, celui-ci met en discussion les questions à l'ordre du jour:

I. Centralisation au B.I.H. des résultats obtenus au cours de l'opération de I933 par toutes les stations participantes.

Le Président fait connaître que 55 stations seulement ont déjà fait parvenir les renseignements demandés. Il demande que les autres stations veuillent bien communiquer leurs documents le plus rapidement possible. 